\title{
Trend Learning Model Through Hybrid Learning
}

\author{
$1^{\text {st }}$ Umi Kulsum \\ Fashion Skill Program \\ SMKN 5 Malang \\ Malang, Indonesia \\ umi_tabus@yahoo.co.id
}

\author{
$2^{\text {nd }}$ Djoko Kustono \\ Mechanical Engineering Engineering Faculty, \\ Universitas Negeri Malang \\ Malang, Indonesia \\ kustono1609@gmail.com
}

\author{
$3^{\text {rd }}$ Purnomo \\ Mechanical Engineering, Engineering \\ Faculty, Universitas Negeri Malang \\ Malang, Indonesia \\ purnomo@um.ac.id
}

\begin{abstract}
The purpose of this research is to know the difference of Hybrid Learning result with learning result. The design of this study was Non-Equivalent Control Group Design, consisting of four treatment groups with varying proportions of hybrid learning, $50 \%, 60 \%$, and $70 \%$, respectively, and the other group were the control group, the untreated group Hybrid Learning 0\%. Sampling technique with purpose sampling. Samples in this study student of class X S MK Program Fashion S kill Administration amounted to 104 students. Place of research in SMK Negeri 5 and 7 Malang. Data analysis technique using AnoSva followed Post Hoc Test with Scheffe. . The result of research showed that there were (1) significant difference of Hybrid Learning with learning result, significance 0.000, (2) difference not significant Hybrid Learning 70 with $60 \%$ to learning result, significance $0,232,(3)$ difference not significant result Hybrid Learning $\mathbf{7 0 \%}$ with $\mathbf{5 0 \%}$ of learning outcomes, sigifikansi 0.475 , (4) significant difference of result of Hybrid Learning $70 \%$ with $0 \%$ (learning of conventional in control group) to learning result of significance $0,000,(5)$ difference of result of Hybrid Learning $60 \%$ with $50 \%$ to learning result significance $0,005,(6)(60)$ with $0 \%$ difference (learning of conventional in control group) on learning result of significance $\mathbf{0 , 0 0 0},(7)$ significant difference of result of Hybrid Learning $50 \%$ with $0 \%$ (conventional learning in the control group) 0.000 significance. Learning through the Hybrid Learning model is recommended as the most effective learning model trend in optimizing the learning process, fostering active, creative, and innovative attitude so that it can motivate in improving learning outcomes.
\end{abstract}

Keywords—hybrid learning, learning outcomes

\section{INTRODUCTION}

The advancement of information and communication technology brings tremendous benefits in education, from utilizing quality learning resources, building scientific discussion forums, to discussions with experts/experts in the world. All can be easily done without limits because each individual can do it himself. Such widespread impact has given new colors in the proven educational system with the abundant development of information technology-based learning models. In its development, the influence of information and communication technology on the world of education is increasingly felt, in line with the shift of learning patterns from face to face that is done conventionally toward the education that has been open by utilizing information technology technology and communication as learning media. Future education will be more determined by an information network that allows interaction and collaboration [1].

In line with the expectation of 21 st century skills, education in Indonesia is now required to prepare students who are smart, creative, and independent and in the future are more likely to develop in the form of open education by applying the distance education system (distance learning). Development of learning by utilizing the use of information technology optimally. The lessons developed tend to combine conventional learning with technology-based learning and communication and communication (ICT). Such learning is known as Hybrid Learning, which combines or combines conventional learning (face-to-face) with learning by utilizing information and communication technology. Through Hybrid Learning the learning system becomes more flexible and not rigid.

The success of learning is the ability to learn in helping students achieve the desired competence. Selection and application of learning model design become one of the determinants of student competency control. One of the competencies that must be mastered by SMK students is the knowledge of Textile which is the basic subjects of vocational competency that require the understanding of the students before studying the vocational competencies of Clothing. One of the goals of Program of Dressmaking Expertise is to equip students with skills, knowledge, and Attitude to be competent in choosing textile or fabric materials. Knowledge of textile/cloth is very important because textile/fabric is the main ingredient in the manufacture of clothing.

Based on data obtained from the results of discussions with textile subject teachers and classroom observations, shows that in general interest in learning Textiles class $\mathrm{X}$ Dress low, which affects the results of learning. Taking note of this, the possibility of learning model that is used less precisely so that it affects the learning outcomes, and less balanced mastery of competencies possessed students. This happens because of lack of innovation in the use of learning models that can construct the ideas and knowledge of students, and optimize the delivery of the material thoroughly so as to improve the competence that affects the results of student learning. The implementation of learning design aims to create a successful learning, which is learning that can help students in achieving 
the competencies as they wish. Therefore, the selection and application of the design of the right learning model will determine the success and mastery of student competence. The learning required is to utilize the element of information technology, by not leaving the direct guidance pattern of the teacher and the utilization of the wider learning resources. This concept combines e-learning with conventional learning (face-to-face) called Hybrid Learning .

Hybrid Learning is also known by various terms including Blended Learning, Hybrid Instruction, Mediated Learning, Technology-Enhanced Instruction, Web-enhanced Instruction, and Web assisted instruction [2]. Although it has various terms in practice all these terms refer to the same proces $s$ that is a combination of face-to-face learning with online learning.

Hybrid Learning is learning that combines or combine learning face to face with computer technology or the internet [3]. Hybrid Learning can cover all areas of science so as to facilitate students and teachers in the process of teaching and learning activities. Through Hybrid Learning activities students become more, student-centered learning, so students are more active in learning. The e-learning-hybrid mode integrates effective learning and methods to eliminate limitations on the availability of time, location, and classroom teachers [4]. E-learning-hybrid can serve as a virtual teacher. In addition, e-learnng-hybrid offers learning assistance when conventional learning (classical learning) that requires the process of face-to-face between teachers and students can not be done. That e-learning provides teaching regardless of place and time of the study [5]. Students can access the subject matter whenever and wherever so there is no time limit to access it.

IMOB Educate Tabloit (2013) publishes Hybrid Learning, described that Hybrid Learning as a relevant learning model in the implementation of the 2013 curriculum which essentially offers a mix of models, methods, tools, resources, and instructional media. This condition is believed to spur the birth of productive, creative, and innovative human beings, who are saving the principle of active student learning (student centered). Learning is not just going on at school, but it can take place at home or in the community. This means that learning can take place in the form of face-to-face and online ssecara hereinafter called Hybrid Learning Model. Some of these statements are supported the statement in his writing on a research book about Hybrid Learning learning [6]. In his writings, the biggest single trend in education today is Hybrid learning. With Hybrid learning various educational advantages when both traditional learning classes and elearning are implemented collectively.

Election and application of learning model of Hybrid Learning as a learning supplement with constructive approach on Textile subject, because it has several advantages, including: (1) enables students to obtain up-to-date teaching materials; (2) teachers can control the mastery of material controlled by the students both in face to face learning or online, (3) learning activities become more effective and efficient by optimizing the utilization of information and communication technology; (4) completing lessons learned in face-to-face learning. Computer-assisted learning can improve the students' interactive and cognitive aspects [7].

Based on these explanations, researchers conducted research with the aim to know the impact of Hybrid Learning can improve student learning outcomes, and know the difference Hybrid Learning results with learning outcomes.

\section{METHOD}

The design in this research is Non-Equivalent Control Group Design. Sampling by purposive sampling technique. The study was divided into four treatment groups with varying proportions of hybrid learning, 50\%, 60\%, and 70\%, respectively. One other group is Control group, group without being treated with $0 \%$ Hybrid Learning (with conventional learning). The sample in this research is the students of class $\mathrm{X}$ of SMK program of Clothing Fashion expertise amounted to 104 students. The research was conducted at SMK Negeri 5 and SMK Negeri 7 Malang. Data analysis techniques using Anova.

\section{RESEARCH RESULT}

After analyzing the data for hypothesis testing then discussed the results of data analysis. The results of data analysis can be seen in the following table.

T ABLE I. ANOVA LEARNING OUTCOMES

\begin{tabular}{|c|r|r|r|r|c|}
\hline & Sum of Squares & df & $\begin{array}{c}\text { Mean } \\
\text { Square }\end{array}$ & F & Sig. \\
\hline Between Groups & 8887.260 & 3 & 2962.420 & 43.012 & .000 \\
\hline Within Groups & 6887.500 & 100 & 68.875 & & \\
\hline Total & 15774.760 & 103 & & & \\
\hline
\end{tabular}

Post Hoc Tests

TABLE II. MULTIPLE COMPARISONS

\begin{tabular}{|c|c|c|c|c|c|c|}
\hline \multirow{2}{*}{$\begin{array}{c}\text { (I) } \\
\text { Hybild_- } \\
\text { Leximin } \\
g\end{array}$} & \multirow{2}{*}{$\begin{array}{l}\text { (J) } \\
\text { Hybrid lea } \\
\text { rning }\end{array}$} & \multirow{2}{*}{$\begin{array}{c}\text { Mean } \\
\text { Difference } \\
\text { (ll-J) }\end{array}$} & \multirow{2}{*}{$\begin{array}{l}\text { Std. } \\
\text { Error }\end{array}$} & \multirow{2}{*}{ Sig. } & \multicolumn{2}{|c|}{$\begin{array}{c}95 \% \text { Confldence } \\
\text { Interval }\end{array}$} \\
\hline & & & & & $\begin{array}{l}\text { Lower } \\
\text { Bound }\end{array}$ & $\begin{array}{l}\text { Upper } \\
\text { Bound }\end{array}$ \\
\hline Bybria & Ay,brld & & & & & \\
\hline \multirow[t]{3}{*}{$\underset{70 \%}{\text { Leaming }}$} & $\begin{array}{c}\text { learning } \\
60 \%\end{array}$ & .4 .80769 & 2.30176 & .232 & .11 .3532 & 1.7378 \\
\hline & $\begin{array}{c}\text { Hybrid } \\
\text { learning } \\
\text { 50\%s }\end{array}$ & $3.653 \mathrm{\Omega 5}$ & 2.30176 & .475 & -2.8916 & 10.1993 \\
\hline & $\begin{array}{c}\text { Hybild } \\
\text { learning } 0 \% 6\end{array}$ & $19.80769^{\circ}$ & 2.30176 & .000 & 13.2622 & 26.3532 \\
\hline \multirow[t]{3}{*}{$\begin{array}{l}\text { Hybrid } \\
\text { Leaming } \\
60 \% 6\end{array}$} & $\begin{array}{c}\text { Hybrid } \\
\text { learning } \\
70 \% 9\end{array}$ & 4.80769 & 2.30176 & .232 & -1.7378 & 11.3532 \\
\hline & $\begin{array}{l}\text { Hybrid } \\
\text { learning } \\
\text { 50\%s }\end{array}$ & $8.46154^{\circ}$ & 2.30176 & .005 & 1.9160 & 15.0070 \\
\hline & $\begin{array}{l}\text { Pyord } \\
\text { learnteg } 6 \% 6\end{array}$ & $24.61538^{\circ}$ & 2.30176 & .000 & 18.0699 & 31.1609 \\
\hline \multirow[t]{3}{*}{$\begin{array}{c}\text { Hybrid } \\
\text { learning } \\
\text { 50\% }\end{array}$} & $\begin{array}{c}\text { Bybrid } \\
\text { learuing } \\
70 \%\end{array}$ & -3.65385 & 2.30176 & .475 & .10 .1993 & 2.8916 \\
\hline & $\begin{array}{l}\text { Bybrid } \\
\text { learning } \\
60 \% s\end{array}$ & $-8.46154^{\circ}$ & 2.30176 & .005 & .15 .0070 & .1 .9160 \\
\hline & $\begin{array}{l}\text { Hybidd } \\
\text { leurning } 6 \% 6\end{array}$ & $16.15385^{\circ}$ & 2.30176 & .000 & 9.6084 & 22.6993 \\
\hline \multirow[t]{3}{*}{$\begin{array}{c}\text { Hybrid } \\
\text { Seaming } \\
0 \%\end{array}$} & $\begin{array}{c}\text { Hybrid } \\
\text { learning } \\
70 \%\end{array}$ & $-19.80769^{\circ}$ & 2.30176 & .000 & .26 .3532 & .13 .2622 \\
\hline & $\begin{array}{l}\text { Aybrid } \\
\text { learning } \\
\text { 60\%s }\end{array}$ & $.24 .61538^{\circ}$ & 2.30176 & .000 & .31 .1609 & .18 .0699 \\
\hline & $\begin{array}{c}\text { Bybrid } \\
\text { leaming } \\
50 \%\end{array}$ & $-16.15385^{4}$ & 2.30176 & .000 & .22 .6993 & -9.6084 \\
\hline
\end{tabular}


Anova test results show (1) differences in Hybrid Learning learning outcomes with learning outcomes, 0.000 significance. Anova test results are followed by Multiple Comparisons of Post Hoc Test with Scheffe, showing differences in Hybrid Learning results with learning outcomes are (2) Hybrid Learning 70\% with $60 \%$ significance of 0.232 , (3) Hybrid Learning $70 \%$ with $50 \%$ significance of 0.475 , (5) Hybrid Learning $60 \%$ with $50 \%$ significance 0.005 , (6) Hybrid Learning $60 \%$ with $0 \%$ (conventional learning) significance 0.000 , (7) Hybrid Learning 50\% with $0 \%$ (conventional learning) significance 0.000 .

\section{DISCUSSION}

The results of this study show (1) there is a significant difference between Hybrid Learning results with learning outcomes with a significance of 0.000 , smaller $(<)$ from the level of significance 0.05 . Post Hoc research results with Scheffe show differences in Hybrid Learning results with learning outcomes (2) $70 \%$ with $60 \%$ significance of 0.232 , meaning $\mathrm{Ho}$ accepted and $\mathrm{H} 1$ rejected, (3) $70 \%$ with $50 \%$ significance 0.475 , meaning Ho accepted and H1 rejected, (5) $60 \%$ with $50 \%$ significance 0.005 , meaning Ho is rejected and H1 accepted, (6) $60 \%$ with $0 \%$ (learning Conventional) significance 0,000 , meaning $\mathrm{Ho}$ is rejected and $\mathrm{H} 1$ accepted, (7) $50 \%$ with $0 \%$ (conventional learning) significance 0.000 , meaning Ho is rejected and $\mathrm{H} 1$ accepted.

The results of this study are in accordance with the proportion of content delivered online written [8]. They provide clear categories of Hybrid Learning, traditional learning, web enhanced, and online learning. Learning is said to be in the form of Hybrid when the portion of e-learning is in the range $30-79 \%$ combined with face to face (face to face learning). On the other hand Hybrid Learning models encourage teachers to change the educational paradigm of teacher-centered learning toward student-centered learning.

This study is supported by the results of research conducted on students' perceptions of the use of digital libraries as part of the Hybrid Learning task [9]. The study was conducted in high school in the Mildwest United States to 154 students. The results showed that students have a positive perception of the use of digital libraries. Students who have more experience with the internet have significantly higher positive perceptions of the use of digital libraries.

Identifying Integration Models Using Adventure Learning [10]. Explained that they understand how teachers choose to integrate Hybrid Online education programs. The data were collected through classroom observations, personal and group interviews, and suggested four models of integration in Hybrid Online education that were curriculum based, activity-based, standards-based, and media-based, especially in out-of-class learning such as adventure learning. The results obtained are recommendations given for the description, development, implementation and integration of Hybrid Online education programs.

In the research aims to explore the perception of the concept of Hybrid learning and to describe the methodology such as face-to-face and instructional component integration online [11]. The use of innovative technology, the reconceptualization of the learning paradigm, or the ongoing assessment and evaluation of mixed learning (Hybrid) show added value to its role in foreign language teaching.

\section{CONCLUSIONS}

Based on the above discussion the results of this study can be concluded that: (1) significant difference result of Hybrid Learning with learning result (2). (3) learning model can increase the independence and learning outcomes, (2) to know the existence of significant relationship of learning independence with learning result, (3) to know the existence of significant difference of Hybrid Learning with learning outcomes, (5) Learning through hybrid learning with $60 \%$ proportion is recommended as the most effective learning model trend in optimizing the learning process, developing self-reliance attitude and active, creative and innovative attitude so that it can motivate in improving student achievement and learning outcomes.

Learning through Hybrid Learning is recommended as the most effective learning model trend in optimizing the learning process, develop the students' self-reliance attitude and active, creative and innovative attitude so that it can motivate in improving student achievement and learning outcomes.

\section{REFERENCES}

[1] W. Prayitno and L. P. M. P. Widyaiswara, "Implementasi Blended Learning dalam Pembelajaran pada Pembelajaran Dasar dan Menengah," 2013.

[2] O. Delialiogle and Z. Yildirim, "Students Perception on Effective Disventions of Interactive Learning is a Blended Learning Environment," Educ. Technol. Soc., no. 2, pp. 133-146, 2009.

[3] I. A. Putra, "Orientasi Hybrid Learning melalui Model Hybrid Learning dengan Berbantuan Multimedia di Dalam Kegiatan Pembelajaran," 2015 .

[4] A. T sai, "A Hybrid E-Learning Model Incorporating Some of The Principak Learning Theories," Soc. Behav. Personal., vol. 39, no. 2, pp. 145-152, 2011.

[5] L. Tasri, "Pengembangan Bahan Ajar Berbasis Web,"MEDITEK, vol. 3 , no. 2, 2011.

[6] F. L. Wang, "Physica A: Statistical Mechanics and its Applications," Carit as Inst. og High. Educ., vol.387, no. 13, pp. 3192-3200, 2008.

[7] P. Resta and T. Laferriere, "T echnology in Support of Collaborative Learning.," Educ. Psycology, no. 19, pp. 65-83, 2007.

[8] I. E. Allen, J. Seamien, and R. Garret, Blending in: The Extent and Promise of Blended Education The United States. Newburypot: The Sloan Consortium, 2007.

[9] A. Koohang, "Students' Perceptions Toward the Use of the Digital Library in Weekly Wb-Based Dist ance Learning Assignments Portion of a Hybrid Programme," Br. J. Educ. Technol., vol. 35, no. 5, pp. 617626, 2004.

[10] A. Doering and G. Veletsianos, "Hybrid Online Education: Identifying Integration Models Using Adventure," Res. Technol. Educ., vol. 4, no. 1 , pp. 23-41, 2008.

[11] M. S. Hom, R. J. Crouser, and M. U. Bers, "T angible Interaction and Learning: The Case for A Hybrid Approach," Persoonal Ubiquotois Comput., vol. 16, no. 4, pp. 379-389, 2012. 